INDEPENDENT JOURNAL OF MANAGEMENT \& PRODUCTION (IJM\&P)

http://www.ijmp.jor.br

v. 12, n. 2, March-April 2021

ISSN: 2236-269X

DOI: 10.14807/ijmp.v12i2.1326

\title{
SOCIOECONOMIC AND PRODUCTIVE MARINE AND ESTUARINE FISHERY ACTIVITY POTENTIAL INDEX
}

\author{
Nathália Fernandes De Castro Alves \\ Universidade Federal do Espírito Santo, CEUNES, Brazil \\ E-mail: nathy_castro10@hotmail.com
}

Rayane Colombi Lorenzoni

Universidade Federal do Espírito Santo, CEUNES, Brazil

E-mail: rayanecl@gmail.com

Vanielle Aparecida do Patrocinio Gomes

Universidade Federal do Espírito Santo, CEUNES, Brazil

E-mail: vaniellea.gomes@hotmail.com

Wellington Gonçalves

Universidade Federal do Espírito Santo, CEUNES, Brazil

E-mail: wellington.goncalves@ufes.br

Rodrigo Randow de Freitas

Universidade Federal do Espírito Santo, CEUNES, Brazil

E-mail: rodrigo.r.freitas@ufes.br

Submission: 4/1/2020

Revision: $7 / 3 / 2020$

Accept: 7/3/2020

\section{ABSTRACT}

Considering the need for increased productivity, consequently providing a safe source of quality food and economic sustenance for numerous families, fishing in the State of Rio de Janeiro is configured in an important way, and with a primarily artisanal and professional nature of small bearing. In addition to the fundamental aspect of human subsistence, fishing is an important economic activity, generating several other businesses and income for other economic sectors, such as transport, storage, processing and sale of products, construction and repair of vessels, and construction of artifacts and utensils, among others. Thus, the study of potentialities and vulnerabilities involving the strengths and weaknesses of the coastal region of Rio de Janeiro will assist in actions in favor of a broad development of activity in the coastal municipalities. For this, the analytic hierarchy process was used, a multicriteria analysis method, to construct hierarchies of these municipalities in terms of potential development, and thus the analysis of the environment was performed using a matrix to analyze the 
DOI: $10.14807 /$ ijmp.v12i2.1326

scenarios. The results point out that due to the importance accorded by the interviewees to the economic sub-index, the municipality of Angra dos Reis stood out in the order of priority of defining the municipality with the highest socioeconomic and productive potentiality index for fishing activity, presenting quantitative data related to sub-indices of greater importance than the other municipalities. However, when the analysis for each subscript was carried out separately, Angra dos Reis has the lowest classification for vulnerability to environmental and social issues.

Keywords: AHP; cluster; Saaty; SWOT analysis

\section{INTRODUCTION}

Fishing is an activity of great historical importance, which, like agriculture and hunting, has been practiced by man since prehistory to obtain the means necessary for subsistence and food (Rodrigues \& Guidice, 2011). In addition to the fundamental aspect of human subsistence, fishing is an important economic activity, generating several other businesses and income for other economic sectors, such as transport, storage, processing and sale of products, construction and repair of vessels, and construction of artifacts and utensils, among others (Silva \& Leitão, 2012).

Similarly, Leite (1991) reports that fishing is of great importance for society: As well as being responsible for the food supply, it also provides a high number of jobs since in the stages of processing and marketing fish, income is also generated for other economic sectors. Let us cite, for example, the working conditions of fishermen, which have improved greatly since the industrial revolution due to advancements in technology, favoring the expansion of fishing, and because of the invention of the steam engine and metal hull. These aspects have predominantly been responsible for greater efficiency and autonomy in capture (Coutinho, 2016).

As for Brazil, according to Rodrigues and Guidice (2011), along 7367 km of Brazilian coast, numerous fishing communities have appeared in the last five centuries of national history. Therefore, it can be verified that the economic potential of fish is significant, and the natural capacity of the country for the development of fishing is highlighted, mainly due to its natural characteristics.

However, even with the country having these cited and desirable characteristics that favor it in relation to sea fishing, Brazilian productivity is still lower compared to other 
DOI: $10.14807 /$ ijmp.v12i2.1326

countries, for example, Chile, Peru, and Japan, where fishing is carried out offshore, mainly due to technological advances. This demonstrates the fact that Brazil has a long way to go (Rodrigues \& Guidice, 2011).

Specifically, regarding the target area of this study, the state of Rio de Janeiro has historically been considered one of the main fishing poles in the country, but today its fishing activity reflects national stagnation due to poor productive, commercial, and financial management. One of the consequences of this inefficient management is an industrial fleet composed primarily of poorly sized and old vessels (Oliveira et al., 2009) and characterized by low technology compared to other fleets of the south-east coast of Brazil, and as opposed to other sites that have observed a greater development in activity, such as the city of Itajaí, Santa Catarina (Vianna, 2009).

Based on the above, this study intended to determine, through a method of decision making, how the region compares with the target localities to indicate the extent of vulnerabilities, and the socioeconomic and productive potential of the fishing activity and estuarine area of the coastal region of the State of Rio de Janeiro, analyzing and structuring them in order of relevance.

For this, the multi-criterial analytic hierarchy process (AHP) was used. Based on Allison et al., (2009), this was employed to identify and hierarchize the municipalities with the best potential. Afterwards, the Primer software was used for an advanced analysis of the multivariate data, in line with Faraco (2012) and Oliveira (2015). Then, the strengths, weakness, opportunities, and threats (SWOT) matrix of Kirchner et al., (2016) was used to help in establishing the potentialities of the municipality that presented the highest hierarchy.

\section{THEORETICAL REVIEW}

\subsection{Fishing Activity}

Abdallah (1998) defines fishing activity as actions that involve the capture and sale of fish. This activity is part of the agro-industrial fish system, which encompasses fishing activity, activities that supply fishery inputs (mainly vessels and nets), and the industrialization and commercialization of fish already processed. Fishing activity occurs in marine, estuarine waters (transition environment and the interface between freshwater rivers, for example, and saline sea) and fresh water. The exploitation of resources occurs in an extractive way (taking fish as a natural renewable resource), and also through non-extractive fishing (Abdallah, 1998). 
INDEPENDENT JOURNAL OF MANAGEMENT \& PRODUCTION (IJM\&P)

http://www.ijmp.jor.br

v. 12, n. 2, March-April 2021

ISSN: 2236-269X

DOI: 10.14807/ijmp.v12i2.1326

Fishing, with its commercial characteristics, has been present in Brazil’s history since colonial times, and is among the oldest and most traditional economic activities in the country. In addition, the preponderance of artisanal fishing in the Brazilian fishing environment constitutes an additional factor in terms of the socio-environmental importance of this sector (Isaac-Nahum, 2006; Rodrigues \& Guidice, 2011). For example, world fish production reached 109.1 million metric tons in 1994, an increase of $11 \%$ over 1993. By continent, fish production in that year was distributed as follows: Asia, 41\%; Europe, 26\%; South America, 18\%; North America, 10\%; Africa, 4\%; Oceania, 1\% (Faveret et al., 1997).

Total fish production in the world showed new growth in the period 2006-2008, from 137 million tons in 2006 to 140 million tons in 2007. China confirmed its role as the main producer with 48 million tons in 2008. Special attention should be paid to the fact that in general, $80 \%$ of the world production of fish and fishery products occurs in developing countries (Nomura, 2010; Andrade \& Schiavetti, 2015).

In Brazil, the sector represents one of the oldest economic activities, going back to the colonial period. However, Tremel (1993) reports that Brazilian coastal waters are poor in nutrients, which limits the potential of the fishery resources. According to the author, there is a considerable number of fish species on the Brazilian coast; however, few are capable of forming stocks that can be exploited economically. It is also worth noting that the sea currents that pass around the Brazilian coast are of high temperatures and salinity, causing low primary productivity (Sacco Dos Anjos et al. 2004).

Analyzing the state of Rio de Janeiro, it has a fishing sector of great socioeconomic relevance in the national scenario (Prozee, 2005), especially with respect to the generation of income and employment for coastal communities (Soares, 2009). Historically, it is considered one of the main fishing poles of the country, but currently activity in the state reflects the public neglect of its management. One of the consequences of the ineffective management of Rio de Janeiro is evident in an industrial fleet composed predominantly of poorly sized and old vessels (Vasconcelos et al., 2007; Oliveira et al., 2009).

\subsection{Multi-Criterial Analytic Hierarchy Process (AHP)}

AHP is the multi-criterial method most widely used to support business decisionmaking in multi-criteria problems. This method is based on the Newtonian and Cartesian way of thinking, which seeks to treat complexity through the decomposition and division of the problem into factors, which can further be decomposed into new, lower, clear, and scalable 
INDEPENDENT JOURNAL OF MANAGEMENT \& PRODUCTION (IJM\&P)

http://www.ijmp.jor.br

v. 12, n. 2, March-April 2021

ISSN: 2236-269X

DOI: $10.14807 /$ ijmp.v12i2.1326

factors, then establishing relationships for later synthesis (Martins et al., 2009; Gomes et al., 2016). This method is based on three stages of analytical thinking:

1) Construction of hierarchies: Using AHP, the problem is organized in hierarchical levels. According to Bornia and Wernke (2001) hierarchical ordering enables the decision maker to gain a visualization of the system as a whole, and its components and their interactions with the system, aiding the decision maker in understanding the problem more comprehensively, and thus helping to assess the scale and content of the criteria through homogeneous comparison of the elements.

2) Priority definition: This is based on the human being's ability to perceive the relationship between observed objects and situations, comparing pairs in light of a particular focus, criterion, or even judgment (Roche \& Vejo, 2004).

The number of judgments required to construct a generic judgment matrix $\mathrm{A}$ is $\mathrm{n}(\mathrm{n}$ 1)/2, where $n$ is the number of elements in the matrix.

3) Establishing logical consistency: In this regard, the human being has the ability to establish relationships between objects or ideas in a way that is coherent, so that there is a good relationship between them and their relationships are consistent (Saaty, 2000). After applying each judge's weights, it is necessary to check if there is any deviation between the comparisons (Gomes \& Freitas, 2018; Gomes et al, 2016).

For the application of AHP, a survey is first performed to analyze the number of samples needed for the study. According to Dresch and Miguel (2015), such surveys have been used in studies to present methodological procedures that allow the researcher to draw conclusions about the studied phenomenon, or the population, using statistical mathematics. These authors affirm that in making use of a survey, the researcher can specify the techniques of data collection and analysis, providing credibility concerning the data obtained, as well as evidence of the rigor adopted and the possibility of future replication of the study.

According to Cay and Uyan (2013), the definition of the population and sample must undertake with care to allow visualization of the phenomenon investigated. Carnevalli et al., (2013) indicate that the survey sample may be non-probabilistic, i.e., the choice of sample elements may not be random. According to Miguel et al., (2012), the total number of elements forming the population influences the entire planning and execution process of the survey. For these reasons Baker et al., (2013) do not recommend working with all the elements that make up a population, but rather with part of it. 
DOI: 10.14807/ijmp.v12i2.1326

The AHP brings as a result of its steps, a ranking with weights for each of the alternatives evaluated, such as, for example, the decision maker will use the alternative weights to make the best choice (Corsi et al., 2020).

\section{METHODOLOGY}

The state of Rio de Janeiro has a coastline of approximately $635 \mathrm{~km}$ in length, with the mouth of the Itabapoana River as its boundary to the north, and bounded by the state of Espírito Santo, and the Ponta de Trindade, in the extreme south, on the border with the state of São Paulo (FIPERJ, 2017).

According to data from the National Reconstruction of Fishermen of Brazil (SEAP, 2007), Rio de Janeiro was the 10th highest state in terms of the number of fishermen registered in the RGP and had 3.4\% of the total number of fishermen in Brazil, with 11,064 men 83.16\%) and 2,241 (16.84\%) women involved in the activity in the state. In Brasilia, a total of 14,874 fishermen registered in Rio de Janeiro (SEAP, 2007) were registered in 2008, during the 2nd Workshop for the Development of the National Fisheries Monitoring Plan.

This study was carried out in the coastal municipalities of the state, considering only marine and estuarine fisheries. The sites studied were: Angra dos Reis, Araruama, Armação dos Búzios, Arraial do Cabo, Cabo Frio, Campos de Goytacazes, Casimiro de Abreu, Duque de Caxias, Iguaba Grande, Itaguaí, Magé, Mangaratiba, Maricá, Niterói, Paraty, Quissamã, Rio das Ostras, Rio de Janeiro, São Francisco de Itabapoana, São Gonçalo, São João da Barra, São Pedro da Aldeia, and Saquarema.

The study problem was defined and three phases were elaborated for the operationalization of the proposed methodological approach, as shown in Figure 2. Based on the large body of literature reviewed, criteria, sub-criteria, and options related to regional development were indicated. Thus, sub-indices, indicators, and criteria served as the basis for the elaboration of a survey, used in the composition of the operationalization of AHP (Dias et al., 2007; Moraes, 2012; Rocha et al., 2012; Teixeira et al., 2012; Evangelista-Barreto et al., 2014; Viegas et al., 2014) (Figure 1). 
DOI: 10.14807/ijmp.v12i2.1326

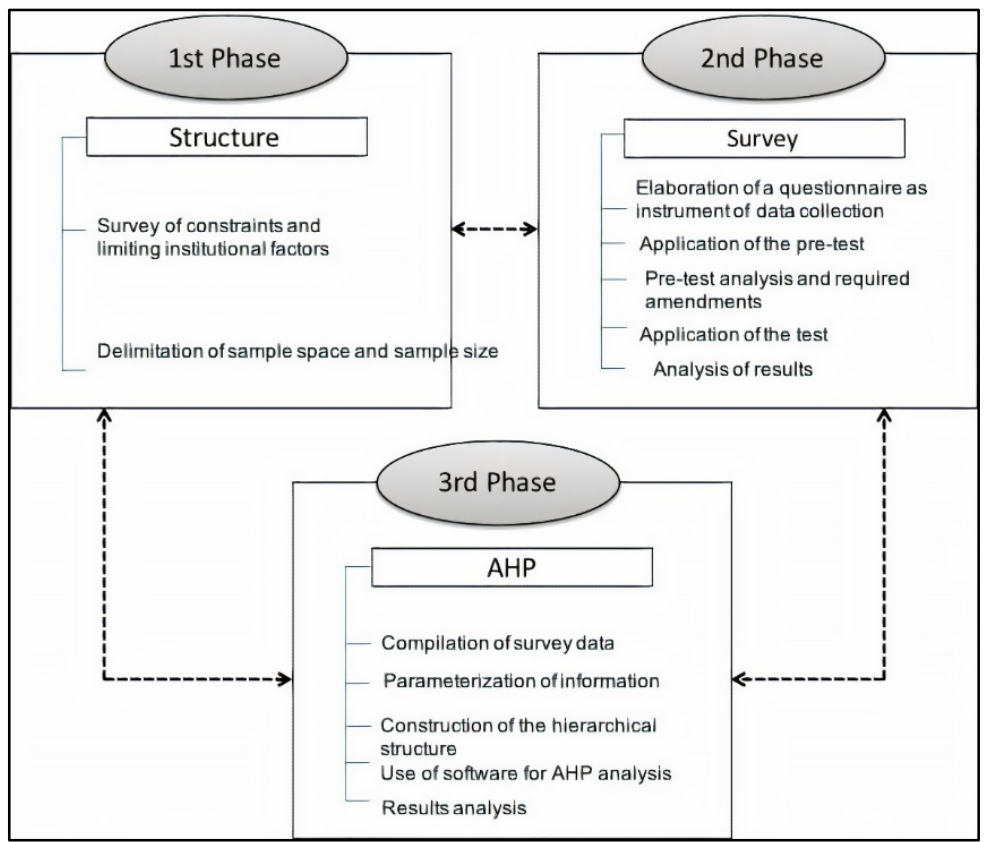

Figure 1: Synthesis of the proposed methodological approach.

For each identified sub-criterion, data were collected referring to the municipalities studied, and the means of these data were configured as analytic criteria to provide a visualization of the relations of proximity between the sub-indices, indicators, and criteria, and corroborate the results observed, considering the degree of importance indicated by the respondents in the survey.

Because the elements of a population are dissimilar, it is necessary to choose which ones will compose the sample. This makes it possible to employ a control procedure that establishes a sample adequate to the objectives of the investigation (Cay \& Uyan, 2013). In this case, experts from the field formed the sample population responding to the questionnaire.

These specialists make their judgments using the Saaty numerical scale, which assigns values from 1 to 9 , determining the relative importance of one item in relation to the other. The judgments of researchers in the area were arranged in matrices and compared by pair, how to apply the method.

The size of the sample, or the number of respondents required for the survey, depends on how large the population is and the desired reliability of the results obtained (Cay \& Uyan, 2013). In this work, the calculation of Dupont and Plummer (1990) was adopted, as given in the following equation 1 :

$n=\frac{Z^{2} \cdot\left(\frac{x}{n}\right) \cdot\left[1-\left(\frac{x}{n}\right)\right] \cdot N}{(N-1) \cdot e^{2}+Z^{2} \cdot\left(\frac{x}{n}\right) \cdot\left[1-\left(\frac{x}{n}\right)\right]}$ 
DOI: 10.14807/ijmp.v12i2.1326

where $\mathrm{n}$ is the sample size, $\mathrm{N}$ represents the size of the population, e is the sample error, $\mathrm{x} / \mathrm{n}$ is the estimated proportion of the items surveyed in the sample (\%), and $\mathrm{Z}$ is the abscissa value of the normal curve associated with the confidence level.

Collection was undertaken through a questionnaire developed in Google Forms and sent to the specialists. Before the questionnaire was completed, a pre-test was performed. According to Goode and Hatt (2017), this is a general test in which each part of the procedure must be designed and implemented exactly as it will be at the actual time of data collection. The pretest was carried out in the week of October 2 to 6, 2017, with university students to certify that the questionnaire was in accordance with the proposed methodology.

On October 11, 2017, an email was sent to 35 specialists with the questionnaire. It was necessary to obtain 26 responses to validate the questionnaire. Those who had not responded by 18 October were again sent the link to the questionnaire. Data collection was completed on November 3, 2017.

After receiving the questionnaires from each judge, it was verified whether there was any deviation between the comparisons, where the consistency ratios (CR) (equation 2) of each specialist were calculated (Saaty, 1990).

$$
\mathrm{CR}=\frac{\mathrm{IC}}{\mathrm{IR}}
$$

Since IC is the Consistency Index, given by $(\lambda \max -n) /(n-1)$, where $\lambda \max$ is the largest eigenvalue of the judgment matrix, and IR is the Randomized Index, standardized and dependent on the $\mathrm{n}$ order of the matrix. If CR was significantly small, that is, about $10 \%$ or less, the judgment is accepted (Saaty, 1990), if this condition is not met, the assessment must be redone or discarded. Finally, at the end of the application of the method, we have the ranking with the weights for each of the alternatives evaluated.

To synthesize the results, hierarchical grouping analyses were performed through clustering and non-parametric multidimensional scaling (MDS) using Primer ${ }^{\circledR}$ software. MDS was used to facilitate the interpretation of results and to show their possible relations, with each event represented by a point in space, and the distance between them representing the relation of similarity (Steyvers, 2002). In this work, MDS measures were constructed for the subindices and indicators, before comparison among municipalities.

To provide a better visualization of the potentialities and vulnerabilities obtained, based on the results obtained through the operationalization of AHP, it was possible to congregate 


\section{INDEPENDENT JOURNAL OF MANAGEMENT \& PRODUCTION (IJM\&P)}

http://www.ijmp.jor.br

v. 12, n. 2, March-April 2021

ISSN: 2236-269X

DOI: 10.14807/ijmp.v12i2.1326

the opinions of the specialists. To carry out a strategic analysis to synthesize the results, the SWOT matrix was used to consolidate the formulation of the socioeconomic and productive potentiality index (IPSP). This analyzes the municipalities that presented extreme results (better and worse comparatively); employing this, the aim is to promote a vision of the development of fishing.

\section{RESULTS}

Based on the matrix of the relative importance of the criteria, derived from AHP, 26 responses were obtained for completion of the matrix according to the participants respective knowledge of the subject. We then calculated the weighted average of each criterion so that it was possible to analyze which criteria the experts considered most important.

Multiplying the averages weighted by the values of the data previously identified, it was possible to elaborate the table of criteria in which the indicators were calculated and analyzed with reference to the 25 municipalities studied. Within each indicator, there are subcriteria; however, these were not used in the formulation of the matrix because the size would make it unviable. The tabulation of criteria for the necessary normalizations was used to calculate the sub-indices for each of the 25 municipalities analyzed (Table 1).

Table 1: Productivity criteria and indicators

\begin{tabular}{|c|c|c|c|c|c|c|c|}
\hline \multicolumn{8}{|l|}{ Productivity Criteria } \\
\hline & $\begin{array}{c}1.1 \\
\text { Ice Factories }\end{array}$ & $\begin{array}{c}1.2 \\
\text { Cold } \\
\text { Chambers }\end{array}$ & $\begin{array}{c}1.3 \\
\text { Landscapes }\end{array}$ & $\begin{array}{c}1.4 \\
\text { Number of } \\
\text { Fishing } \\
\text { Vessels }\end{array}$ & $\begin{array}{c}1.5 \\
\text { Colonies }\end{array}$ & $\begin{array}{c}1.6 \\
\text { Gas } \\
\text { Stations }\end{array}$ & $\begin{array}{c}1.7 \\
\text { Fishing } \\
\text { Deployment/ } \\
\text { Discharge }\end{array}$ \\
\hline Angra dos Reis & 22,61538 & 60,923076 & 12,6153846 & 540,76923 & 6,692307 & 5,38461 & 7,846153846 \\
\hline Araruama & 0 & 30,461538 & 0 & 321,53846 & 0 & 5,38461 & 0,007846154 \\
\hline $\begin{array}{l}\text { Armação dos } \\
\text { Búzios }\end{array}$ & 15,07692 & 91,384615 & 0 & 350,76923 & 0 & 0 & 0 \\
\hline Arraial do Cabo & 7,538461 & 76,153846 & 0 & 153,46153 & 6,692307 & 5,38461 & 0,009415385 \\
\hline Cabo Frio & 22,61538 & 106,61538 & 12,6153846 & 160,76923 & 6,692307 & 59,2307 & 0,608076923 \\
\hline $\begin{array}{l}\text { Campos de } \\
\text { Goytacazes }\end{array}$ & 22,61538 & 114,23076 & 0 & 511,53846 & 6,692307 & 86,1538 & 0,008630769 \\
\hline Casimiro de Abreu & 0 & 45,692307 & 0 & 263,07692 & 0 & 16,1538 & 0 \\
\hline Duque de Caxias & 7,538461 & 76,153846 & 0 & 190 & 0 & 172,307 & 0 \\
\hline Iguaba Grande & 0 & 45,692307 & 0 & 153,46153 & 0 & 0 & 0,003923077 \\
\hline Itaboraí & 0 & 22,846153 & 0 & 263,07692 & 0 & 86,1538 & 0 \\
\hline Itaguaí & 15,07692 & 380,76923 & 6,30769230 & 241,15384 & 0 & 37,6923 & 0 \\
\hline Macaé & 15,07692 & 83,769230 & 6,30769230 & 255,76923 & 6,692307 & 43,0769 & 0,104353846 \\
\hline Magé & 22,61538 & 45,692307 & 12,6153846 & 4384,6153 & 6,692307 & 5,38461 & 0 \\
\hline Mangaratiba & 15,07692 & 83,769230 & 0 & 365,38461 & 6,692307 & 0 & 0 \\
\hline Maricá & 7,538461 & 60,923076 & 0 & 650,38461 & 0 & 10,7692 & 0 \\
\hline Niterói & 37,69230 & 38,076923 & 31,5384615 & 3471,1538 & 13,38461 & 80,7692 & 4,291061538 \\
\hline Paraty & 15,07692 & 53,307692 & 6,30769230 & 226,53846 & 6,692307 & 5,38461 & 0,063553846 \\
\hline Quissamã & 0 & 15,230769 & 0 & 153,46153 & 0 & 0 & 0 \\
\hline
\end{tabular}


INDEPENDENT JOURNAL OF MANAGEMENT \& PRODUCTION (IJM\&P)

http://www.ijmp.jor.br

v. 12, n. 2, March-April 2021

ISSN: 2236-269X

DOI: $10.14807 /$ ijmp.v12i2.1326

\begin{tabular}{l|r|r|r|r|r|r|r}
\hline Rio das Ostras & 0 & 22,846153 & 6,30769230 & 153,46153 & 6,692307 & 16,1538 & 0 \\
Rio de Janeiro & 113,0769 & 533,07692 & 37,8461538 & 387,30769 & 40,15384 & 1496,92 & 0,012553846 \\
\hline $\begin{array}{l}\text { São Francisco de } \\
\text { Itabapoana }\end{array}$ & 22,61538 & 121,84615 & 0 & 1059,6153 & 6,692307 & 0 & 0,010984615 \\
\hline São Gonçalo & 22,61538 & 91,384615 & 25,2307692 & 3456,5384 & 6,692307 & 150,769 & 0,914861538 \\
\hline São João da Barra & 7,538461 & 91,384615 & 12,6153846 & 489,61538 & 6,692307 & 0 & 0,130246154 \\
\hline $\begin{array}{l}\text { São Pedro da } \\
\text { Aldeia }\end{array}$ & 15,07692 & 38,076923 & 0 & 168,07692 & 6,692307 & 53,8461 & 0,013338462 \\
\hline Saquarema & 7,538461 & 68,538461 & 0 & 138,84615 & 0 & 0 & 0,002353846 \\
\hline
\end{tabular}

Using the judgments obtained from the 26 participants in the area who responded to the questionnaire sent by e-mail, an inconsistency test was performed (Saaty, 2000); no matrix was discarded due to failure to attain a consistency ratio greater than $10 \%$. Based on the results obtained, a calculation was performed to construct a new matrix of importance, relating the values of the criteria to the respective sub-indices (Table 2).

Table 2: Matrix of relative importance between subscripts

\begin{tabular}{c|c|c|c|c|c|c|c|c|c|c|c}
\hline $\begin{array}{c}\text { Matrix of relative } \\
\text { importance } \\
\text { between } \\
\text { subscripts }\end{array}$ & 1.1 & 1.2 & 2.1 & 2.2 & 3.1 & 3.2 & 3.3 & 3.4 & 3.5 & 4.1 & $\frac{2}{2.00}$ \\
1.1 & $\mathbf{1 . 0 0}$ & $\mathbf{0 . 1 4}$ & $\mathbf{7 . 0 0}$ & $\mathbf{0 . 3 3}$ & $\mathbf{0 . 3 3}$ & $\mathbf{3 . 0 0}$ & $\mathbf{3 . 0 0}$ & $\mathbf{0 . 2 0}$ & $\mathbf{7 . 0 0}$ & $\mathbf{9 . 0 0}$ & 3.10 \\
1.2 & $\mathbf{7 . 0 0}$ & $\mathbf{1 . 0 0}$ & $\mathbf{7 . 0 0}$ & $\mathbf{5 . 0 0}$ & $\mathbf{5 . 0 0}$ & $\mathbf{7 . 0 0}$ & $\mathbf{7 . 0 0}$ & $\mathbf{3 . 0 0}$ & $\mathbf{7 . 0 0}$ & $\mathbf{9 . 0 0}$ & 5.80 \\
2.1 & $\mathbf{0 . 1 4}$ & $\mathbf{0 . 1 4}$ & $\mathbf{1 . 0 0}$ & $\mathbf{0 . 1 4}$ & $\mathbf{0 . 1 4}$ & $\mathbf{0 . 2 0}$ & $\mathbf{0 . 2 0}$ & $\mathbf{0 . 1 1}$ & $\mathbf{3 . 0 0}$ & $\mathbf{5 . 0 0}$ & $\mathbf{1 . 0 1}$ \\
2.2 & $\mathbf{3 . 0 0}$ & $\mathbf{0 . 2 0}$ & $\mathbf{7 . 0 0}$ & $\mathbf{1 . 0 0}$ & $\mathbf{3 . 0 0}$ & $\mathbf{5 . 0 0}$ & $\mathbf{7 . 0 0}$ & $\mathbf{0 . 3 3}$ & $\mathbf{7 . 0 0}$ & $\mathbf{9 . 0 0}$ & $\mathbf{4 . 2 5}$ \\
3.1 & $\mathbf{3 . 0 0}$ & $\mathbf{0 . 2 0}$ & $\mathbf{7 . 0 0}$ & $\mathbf{0 . 3 3}$ & $\mathbf{1 . 0 0}$ & $\mathbf{5 . 0 0}$ & $\mathbf{5 . 0 0}$ & $\mathbf{0 . 3 3}$ & $\mathbf{7 . 0 0}$ & $\mathbf{9 . 0 0}$ & 3.79 \\
3.2 & $\mathbf{0 . 3 3}$ & $\mathbf{0 . 1 4}$ & $\mathbf{5 . 0 0}$ & $\mathbf{0 . 2 0}$ & $\mathbf{0 . 2 0}$ & $\mathbf{1 . 0 0}$ & $\mathbf{3 . 0 0}$ & $\mathbf{0 . 1 4}$ & $\mathbf{5 . 0 0}$ & $\mathbf{7 . 0 0}$ & 2.20 \\
3.3 & $\mathbf{0 . 3 3}$ & $\mathbf{0 . 1 4}$ & $\mathbf{5 . 0 0}$ & $\mathbf{0 . 1 4}$ & $\mathbf{0 . 2 0}$ & $\mathbf{0 . 3 3}$ & $\mathbf{1 . 0 0}$ & $\mathbf{0 . 2 0}$ & $\mathbf{5 . 0 0}$ & $\mathbf{7 . 0 0}$ & $\mathbf{1 . 9 4}$ \\
3.4 & $\mathbf{5 . 0 0}$ & $\mathbf{0 . 3 3}$ & $\mathbf{9 . 0 0}$ & $\mathbf{3 . 0 0}$ & $\mathbf{3 . 0 0}$ & $\mathbf{7 . 0 0}$ & $\mathbf{5 . 0 0}$ & $\mathbf{1 . 0 0}$ & $\mathbf{7 . 0 0}$ & $\mathbf{9 . 0 0}$ & $\mathbf{4 . 9 3}$ \\
3.5 & $\mathbf{0 . 1 4}$ & $\mathbf{0 . 1 4}$ & $\mathbf{0 . 3 3}$ & $\mathbf{0 . 1 4}$ & $\mathbf{0 . 1 4}$ & $\mathbf{0 . 2 0}$ & $\mathbf{0 . 2 0}$ & $\mathbf{0 . 1 4}$ & $\mathbf{1 . 0 0}$ & $\mathbf{5 . 0 0}$ & $\mathbf{0 . 7 4}$ \\
4.1 & $\mathbf{0 . 1 1}$ & $\mathbf{0 . 1 1}$ & $\mathbf{0 . 2 0}$ & $\mathbf{0 . 1 1}$ & $\mathbf{0 . 1 1}$ & $\mathbf{0 . 1 4}$ & $\mathbf{0 . 1 4}$ & $\mathbf{0 . 1 1}$ & $\mathbf{0 . 2 0}$ & $\mathbf{1 . 0 0}$ & $\mathbf{0 . 2 2}$ \\
\hline
\end{tabular}

Items 1.1 and 1.2 refer to the productive subscript, items 2.1 and 2.2 encompass the social subscript, items 3.1 to 3.5 refer to the economic sub-index, and item 4.1 represents the environmental sub-index.

Analyzing the data, according to the respondents' judgment, the economic sub-index represents 44\%, followed by the productive sub-index (38\%), and the social and environmental sub-indices (17\% and 1\%, respectively). This is in contrast to the state of Espírito Santo where, according to Gomes (2018), the subscript that has the greatest weight is the productivity subscript (57.85\%), followed by the economic subscript (27.75\%), and the social and environmental subscripts (13.08\% and 1.32\%, respectively).

The analysis of the sub-indices was performed separately. Among the indicators most relevant in the economic subscript was the management instrument, having the greatest weight (23.46\%); the lowest economic indicator concerned legal organizations (1.42\%). 
DOI: 10.14807/ijmp.v12i2.1326

Concerning the data obtained through the application of AHP, considering the weights of the criteria, and based on these the weights of the subscripts, the economic sub-index, which is composed of municipal public management indicators, public and private institutions, tourism and leisure infrastructure, economic activities and public finance, and the productivity sub-index, which encompasses the indicators of fishing infrastructure and fish stocks/landings, were considered the most important according to the experts’ opinion.

The productive subscript, consisting of seven indicators, indicates fishery/landing stock as the most important (25.90\%) and gas stations as the least productive indicator (1.75\%). In relation to the social index, the most relevant indicator is basic sanitation (24.20\%), whereas the lowest weight is for the age group (1.06\%). In contrast, for the environmental sub-index, which is less important than the others, the most important indicator is soil occupation density (74.9\%) and the least important is agricultural productivity (25.10\%).

Analyzing the indicators in general, the indicator with the highest weight is the management tool (economic subscript) at $7.91 \%$ and the least important is the agricultural productivity indicator (environmental subscript) at $0.32 \%$.

The relative weights found for each subscript were normalized to establish their individual relevance. Thus, the values were multiplied by the quantitative data initially collected from each of the 25 municipalities treated in this study. After regularizing the results, it was possible to elaborate their prioritization based on the average importance the interviewees accorded each element.

A hierarchy of the municipalities can be presented with reference to the sub-indices, thus responding to the general objective. Here, among the municipalities of the coast of Rio de Janeiro with the highest IPSP in terms of fishing activity based on AHP is the municipality of Angra dos Reis (20.85\%), followed by Niterói and Rio de Janeiro (12.87\% and 11.15\%, respectively). The municipalities with the lowest indices were Iguaba Grande (1.65\%) and São Pedro da Aldeia (1.65\%) (Figure 2). 
INDEPENDENT JOURNAL OF MANAGEMENT \& PRODUCTION (IJM\&P)

http://www.ijmp.jor.br

v. 12, n. 2, March-April 2021

ISSN: 2236-269X

DOI: 10.14807/ijmp.v12i2.1326

\begin{tabular}{|c|c|c|c|c|c|c|c|c|c|c|c|}
\hline CRITERIA & 1.1 & 1.2 & 2.1 & 2.2 & 3.1 & 3.2 & 3.3 & 3.4 & 3.5 & 4.1 & \\
\hline VECTORS & 0,080 & 0,296 & 0,022 & 0,151 & 0,119 & 0,052 & 0,042 & 0,210 & 0,018 & 0,010 & INDEX \\
\hline Angra dos reis & 0,044 & 0,559 & 0,038 & 0,031 & 0,047 & 0,039 & 0,046 & 0,113 & 0,023 & 0,017 & $20,855 \%$ \\
\hline Araruama & 0,002 & 0,001 & 0,037 & 0,045 & 0,031 & 0,031 & 0,005 & 0,021 & 0,007 & 0,107 & $1,887 \%$ \\
\hline Arrmaçāo dos Búzios & 0,012 & 0,000 & 0,042 & 0,039 & 0,043 & 0,028 & 0,004 & 0,062 & 0,004 & 0,017 & $2,785 \%$ \\
\hline Arraial do Cabo & 0,022 & 0,001 & 0,042 & 0,041 & 0,037 & 0,019 & 0,004 & 0,016 & 0,004 & 0,000 & $1,803 \%$ \\
\hline Cabo Frio & 0,050 & 0,043 & 0,040 & 0,038 & 0,031 & 0,037 & 0,019 & 0,066 & 0,016 & 0,028 & $4,433 \%$ \\
\hline Campos de Goyt & 0,039 & 0,001 & 0,038 & 0,044 & 0,042 & 0,058 & 0,024 & 0,028 & 0,041 & 0,046 & $2,693 \%$ \\
\hline Casimiro de Abreu & 0,003 & 0,000 & 0,033 & 0,037 & 0,039 & 0,035 & 0,010 & 0,020 & 0,005 & 0,054 & $1,836 \%$ \\
\hline Duque de Caxias & 0,021 & 0,000 & 0,047 & 0,039 & 0,040 & 0,049 & 0,012 & 0,018 & 0,050 & 0,018 & $2,137 \%$ \\
\hline Iguaba Grande & 0,002 & 0,000 & 0,041 & 0,045 & 0,028 & 0,028 & 0,001 & 0,016 & 0,002 & 0,027 & $1,645 \%$ \\
\hline Itaborai & 0,008 & 0,000 & 0,041 & 0,040 & 0,039 & 0,036 & 0,009 & 0,034 & 0,011 & 0,037 & $2,207 \%$ \\
\hline Itaguai & 0,033 & 0,000 & 0,039 & 0,041 & 0,030 & 0,031 & 0,002 & 0,032 & 0,008 & 0,259 & $2,439 \%$ \\
\hline Macaé & 0,036 & 0,007 & 0,037 & 0,031 & 0,052 & 0,054 & 0,005 & 0,036 & 0,121 & 0,041 & $3,009 \%$ \\
\hline Magé & 0,043 & 0,000 & 0,039 & 0,045 & 0,027 & 0,040 & 0,005 & 0,023 & 0,010 & 0,028 & $2,200 \%$ \\
\hline Mangaratiba & 0,026 & 0,000 & 0,035 & 0,042 & 0,040 & 0,010 & 0,005 & 0,047 & 0,008 & 0,031 & $2,487 \%$ \\
\hline Maricá & 0,008 & 0,000 & 0,038 & 0,040 & 0,040 & 0,008 & 0,003 & 0,016 & 0,019 & 0,027 & $1,672 \%$ \\
\hline Niterói & 0,093 & 0,306 & 0,054 & 0,051 & 0,044 & 0,063 & 0,056 & 0,049 & 0,037 & 0,000 & $12,876 \%$ \\
\hline Paraty & 0,032 & 0,005 & 0,032 & 0,034 & 0,039 & 0,034 & 0,035 & 0,045 & 0,006 & 0,020 & $2,740 \%$ \\
\hline Quissamā & 0,001 & 0,000 & 0,029 & 0,032 & 0,037 & 0,010 & 0,003 & 0,043 & 0,006 & 0,014 & $1,997 \%$ \\
\hline Rio das Ostras & 0,023 & 0,000 & 0,037 & 0,033 & 0,033 & 0,035 & 0,004 & 0,084 & 0,011 & 0,042 & $3,176 \%$ \\
\hline Rio de Janeiro & 0,331 & 0,001 & 0,061 & 0,048 & 0,080 & 0,161 & 0,723 & 0,105 & 0,303 & 0,011 & $11,147 \%$ \\
\hline São Francisco de Itabap & 0,032 & 0,001 & 0,038 & 0,037 & 0,036 & 0,043 & 0,000 & 0,018 & 0,004 & 0,069 & $2,010 \%$ \\
\hline Sāo Gonçalo & 0,070 & 0,065 & 0,056 & 0,039 & 0,040 & 0,074 & 0,009 & 0,009 & 0,027 & 0,021 & $4,374 \%$ \\
\hline Sāo Joāo da barra & 0,035 & 0,009 & 0,033 & 0,051 & 0,046 & 0,038 & 0,010 & 0,071 & 0,268 & 0,025 & $4,173 \%$ \\
\hline Sāo Pedro da Aldeia & 0,029 & 0,001 & 0,037 & 0,035 & 0,040 & 0,002 & 0,004 & 0,011 & 0,005 & 0,043 & $1,646 \%$ \\
\hline Saquarema & 0,007 & 0,000 & 0,037 & 0,041 & 0,038 & 0,038 & 0,002 & 0,016 & 0,005 & 0,015 & $1,775 \%$ \\
\hline
\end{tabular}

Figure 2: Hierarchy of municipalities

Identifying the municipalities with the highest IPSP, we sought to analyze how each site is classified individually in each subscript. For this, a new calculation of the vectors was carried out, this time taking as the basis of the calculation only the subscripts: productivity, and environmental, social, and economic indicators. The mean of the indicators for each subscript was used (Table 3).

Table 3: Hierarchy of municipalities

\begin{tabular}{|c|c|c|c|}
\hline Production Subscript & $\begin{array}{l}1^{\text {st }} \\
2^{\text {nd }} \\
3^{\text {rd }} \\
4^{\text {th }} \\
\end{array}$ & $\begin{array}{l}\text { Angra dos Reis } \\
\text { Niterói } \\
\text { Rio de Janeiro } \\
\text { São Gonçalo } \\
\end{array}$ & $\begin{array}{l}30.16 \% \\
19.93 \% \\
16.61 \% \\
6.77 \% \\
\end{array}$ \\
\hline Social Subscript & $\begin{array}{l}1^{\text {st }} \\
2^{\text {nd }} \\
3^{\text {rd }} \\
4^{\text {th }}\end{array}$ & $\begin{array}{l}\text { Rio de Janeiro } \\
\text { Niterói } \\
\text { São Gonçalo } \\
\text { Iguaba Grande }\end{array}$ & $\begin{array}{l}5.45 \% \\
5.24 \% \\
4.75 \% \\
4.31 \%\end{array}$ \\
\hline Economic Sub-Index & $\begin{array}{l}1^{\text {st }} \\
2^{\text {nd }} \\
3^{\text {rd }} \\
4^{\text {th }}\end{array}$ & $\begin{array}{l}\text { Rio de Janeiro } \\
\text { São Gonçalo } \\
\text { Macaé } \\
\text { Angra dos Reis }\end{array}$ & $\begin{array}{l}27.45 \% \\
8.65 \% \\
5.37 \% \\
5.36 \%\end{array}$ \\
\hline Environmental Sub-Index & $1^{\text {st }}$ & Itaguaí & $25.89 \%$ \\
\hline
\end{tabular}


DOI: $10.14807 /$ ijmp.v12i2.1326

\begin{tabular}{l|l|l|l}
\hline $2^{\text {nd }}$ & Araruama & $10.67 \%$ \\
$3^{\text {rd }}$ & São Francisco de Itabapoana & $6.89 \%$ \\
$4^{\text {th }}$ & Casimiro de Abreu & $5.44 \%$ \\
\hline
\end{tabular}

To provide a better visualization of the similarity between the municipalities, the hierarchical groupings of each subscript and the similarity between the municipalities were analyzed, adding all the subscripts, as shown in Figures 3 and 4.

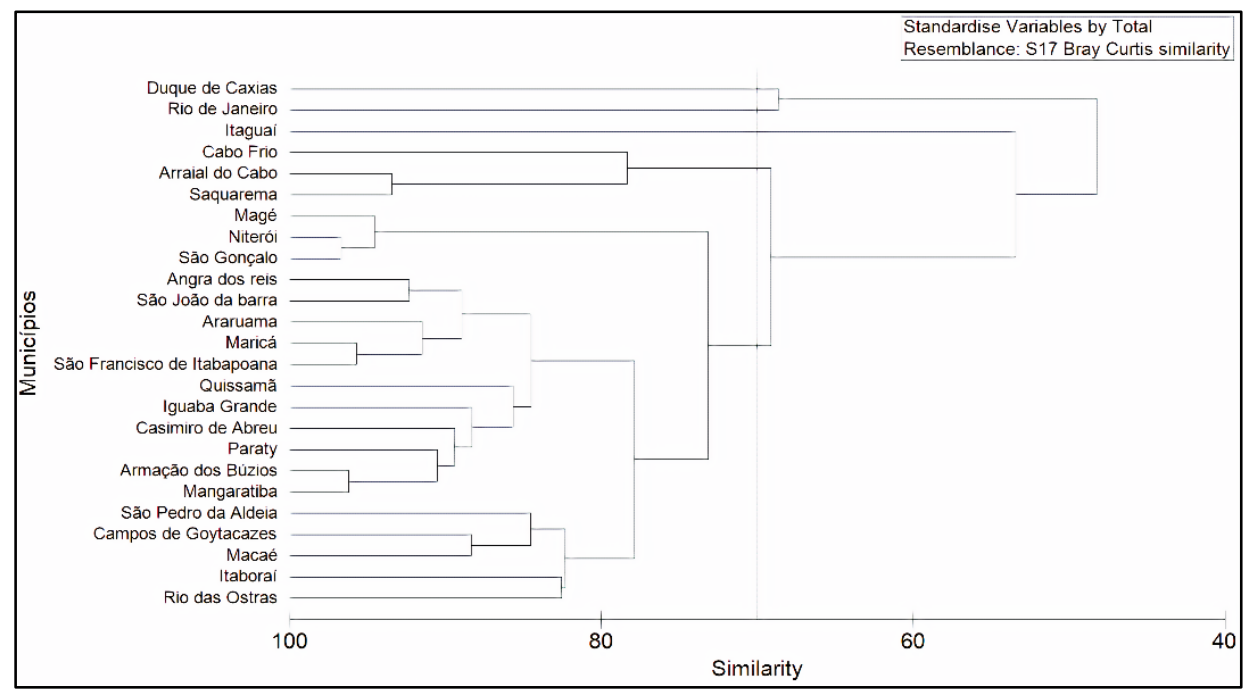

Figure 3: Global similarity dendrogram for the municipalities analyzed.

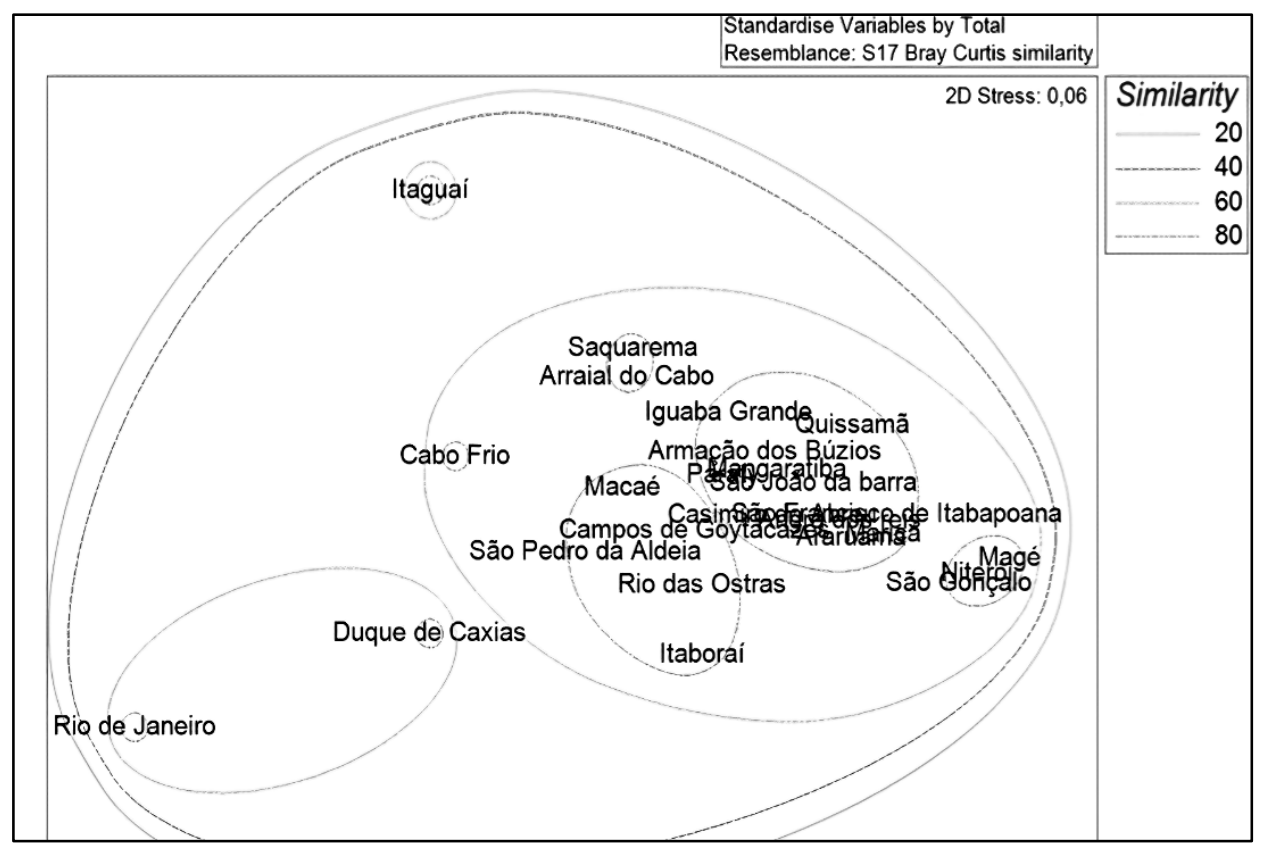

Figure 4: MDS of the global similarity between the analyzed municipalities.

It is possible to perceive the little similarity that the city of Rio de Janeiro has with the other municipalities of the state, being a little in relation to the municipality of Duque de Caxias, due to the environmental subscript, which has a similarity of around $90 \%$. The little 
DOI: $10.14807 /$ ijmp.v12i2.1326

similarity that the municipality of Itaguaí has with the other municipalities is evident, but this difference does not occur when the municipality is analyzed for each subscript separately.

Performing an individual analysis of each sub-index, it can be noted that in terms of the economic perspective, the municipalities of São Gonçalo and Macaé have a degree of similarity of approximately $80 \%$, while Rio de Janeiro exhibits a considerable difference, with slightly less than $40 \%$ similarity to the other municipalities. This may be due to the fact that Rio de Janeiro is a national metropolis and is thus considered the cultural capital of the country, receiving more government resources and more tourists; consequently, it is the busiest economy (Medeiros Junior, 2011).

In relation to the productivity sub-index, the municipalities of Angra dos Reis and Niterói have a similarity index of approximately 80\%, while São Gonçalo and Niterói have a similarity index of around 95\%. Rio de Janeiro presents less than 40\% similarity with other coastal municipalities. However, Rio de Janeiro, São Gonçalo, and Niterói have approximately 90\% similarity when compared for the social subscript, while for the environmental sub-index Casimiro de Abreu and São Francisco de Itabapoana have almost 100\% similarity.

When the MDS was elaborated, the data collected and relative weights were taken into consideration for the analysis of the indicators. The regional analysis confirms the similarity obtained from the dendrogram shown previously in Figure 7. Indeed, analyzing each municipality separately, it can be observed that a considerable proportion of the indicators is grouped in the range of a similarity of $40 \%$.

To diagnose the scenario concerning fishing activity along the coast of Rio de Janeiro, SWOT matrices were elaborated, as shown in Table V. These indicate that the municipality of Angra dos Reis attained values for higher socioeconomic and productivity indices. In contrast, the municipality of Iguaba Grande was among those obtaining the lowest values for the indices, thus presenting a better visualization of the identified potentialities and risks (Tables 4 and 5).

Table 4: SWOT analysis of Angra dos Reis

\begin{tabular}{ll|l|l}
\hline \multirow{2}{*}{ SWOT } & \multicolumn{3}{l}{ External Analysis } \\
\cline { 3 - 4 } & SPPORTUNITIES & THREATS \\
\hline & $\begin{array}{l}\text { 1.2 Fishing stock/landing } \\
\text { 3.1 Municipal public } \\
\text { management }\end{array}$ & 2.2 Social conditions \\
\cline { 3 - 4 } & WEAK POINTS & 2.1 Demography & 3.2 Public and private institutions \\
& & 3.3 Tourism and leisure infrastructure \\
\end{tabular}


INDEPENDENT JOURNAL OF MANAGEMENT \& PRODUCTION (IJM\&P)

http://www.ijmp.jor.br

v. 12, n. 2, March-April 2021

ISSN: 2236-269X

DOI: $10.14807 /$ ijmp.v12i2.1326

Table 5: SWOT analysis of Iguaba Grande

\begin{tabular}{|c|c|c|c|}
\hline \multirow{2}{*}{ SWOT } & \multicolumn{3}{|c|}{ External Analysis } \\
\hline & & OPPORTUNITIES & THREATS \\
\hline \multirow{2}{*}{ 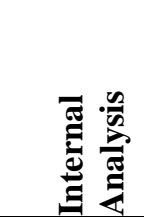 } & $\begin{array}{l}\text { STRONG } \\
\text { POINTS }\end{array}$ & & $\begin{array}{l}\text { 1.1 Fisheries infrastructure } \\
\text { 1.2 Fishing stock/landing } \\
\text { 3.1 Municipal public management }\end{array}$ \\
\hline & $\begin{array}{l}\text { WEAK } \\
\text { POINTS }\end{array}$ & 2.2 Social conditions & 4.1 Land use \\
\hline
\end{tabular}

\section{DISCUSSION}

By acquiring important information covering socioeconomic, technological, and management characteristics it is possible to carry out a diagnosis of fisheries through multidimensional analyzes, facilitating the perception of problems and positive aspects in fisheries (Pizetta, 2004). The results obtained by the weighted averages show that the criteria identified by the experts considered basic sanitation, management instruments, and fishery/landing stock to be more important than other aspects. According to Brasil (1990) basic sanitation is important because its condition exerts a significant influence on the health of the people of the region, and consequently affects fishing activity.

Management tools, according to Domanski (2014), allow a range of activities in relation to the course of a process or set of activities, including monitoring, evaluation, making suggestions, taking decisions, and undertaking interventions or changes, to achieve a certain objective. In this work, management tools are extremely important for fisheries since their development depends on good public management. Campos (1999) also draws attention to the importance of fish stocks, which play a decisive role in the social and economic arena, especially concerning the destinations of artisanal fisher folk populations.

Within the economic sub-index, as the most important in the analysis of the criteria, the most significant was management tools, including the instruments of municipal planning and urban policy. Herein, it is possible to determine that the municipality with the highest investment in government is the municipality of Rio de Janeiro. However, according to the Fundação PROMAR (2005) and Vasconcellos et al. (2007), most communities suffer from poor infrastructure, poor marketing, and a lack of financial support.

It should be noted that there was some difficulty on the part of the authors in identifying the data related to the productivity subscript due to the lack of study in this area and the lack of availability of data from the government of the State of Rio de Janeiro. It can be observed that the criterion carrying the greatest weight is fishery/landing stock, which is the average in terms of the participation of the municipalities in state production. 
DOI: 10.14807/ijmp.v12i2.1326

However, it can also be noted that the schooling level of a large part of the population is low; as Vianna (2009) observed, 75\% of the fishing population of the State of Rio de Janeiro has incomplete primary education and this scenario indicates that fishermen lack education in relation to the majority of the Brazilian population. Among the main limitations, we find that certain categories of fishermen spend weeks at sea. At the end of a fishing enterprise, others need to dedicate themselves to different activities, even if this is rest or leisure, and they do not have time to dedicate to routine attendance in the classroom.

It should also be mentioned that the expectation of assistance is still strong. It is not uncommon for fishermen to expect to receive some financial benefit (e.g., scholarships) to engage in social programs. Carvalho and Callou (2008) note that in the case of the Pescando Letters Assistance Program, the fact that it is linked to the Brazil Alphabetized Program means that fishermen do not distinguish or do not privilege the program proposal.

Most of the results found in the social subscript were easy to obtain because the necessary information is available on the IBGE website, and the most important criterion is basic sanitation, which encompasses the collection and treatment of sewage in the region. The cities with the highest sanitation indices are Arraial do Cabo and Quissamã, which encompass $100 \%$ of the sewage collected and treated.

Based on the hierarchical analysis, it was possible to verify that two of the indicators with the highest relative weights (fish stocks/landing and economic activities) present quantitative data with greater representativeness for the municipality of Angra dos Reis, which is prioritized in relation to its IPSP. Thus, even when analyzing each sub-index separately, the municipality of Angra dos Reis ranks first only for the productivity subscript and fourth in the economic sub-index, as shown in Table VI.

The same case arises for the municipality of Conceição da Barra in the state of Espírito Santo according to Gomes (2018): The city has a higher IPSP and is highly relevant only in the productivity subscript. The municipalities of São Gonçalo and Rio de Janeiro are most frequently classified in the individual sub-indices, but they are not those with the highest IPSP; this is because when analyzed in relation to all the sub-indices, the importance of these municipalities decreases.

When analyzing the final index, it can be observed that the municipalities with the highest indices, Angra dos Reis, Niterói, and Rio de Janeiro, present some discrepancies when compared to the other coastal municipalities of the State of Rio de Janeiro. The other 
DOI: 10.14807/ijmp.v12i2.1326

municipalities exhibit greater similarity. This is also observed when measuring the sub-indices and criteria: It is noted that the results strengthen the similarity of the higher weight subscripts, and there is great inequality among the lower weight subscripts.

Moreover, Angra dos Reis, which has the highest score in the productivity subscript, and São Gonçalo, which obtained the fourth highest score, benefit from their locations. According to Vianna (2009), there is a public fishing terminal in Angra dos Reis that garners a large part of the landings of the region's industrial fleet. A similar occurrence can be observed in the metropolitan region of the state, in which a group of fishing owners concentrate their landings on the old pier of Sardinha Factory 88, on Conceição Island, in the municipality of São Gonçalo.

As for the analysis of the results, from the SWOT matrices elaborated, it is possible to visualize the potentialities and possible vulnerabilities found in the municipalities studied. For example, in the cities with the highest indices, it can be noted that public management is a strong point of opportunity as with governmental incentives and support for fishermen their activities have great chances of improvement. In contrast, public and private institutions, and tourism and leisure infrastructure are weak threat spots in both municipalities; it is thus important that these issues are explored as they open up opportunities for improving fishing conditions and fisheries development, as well as increasing tourism in the region, which would increase fish consumption.

In the two municipalities with the lowest indices, Iguaba Grande and São Pedro da Aldeia, there are almost no opportunities, but the threats are great. It can be noted that fishing infrastructure and fishery/landing stocks are strong threat points, which only confirms why these municipalities score so low. These points should be analyzed and improved in order for the fishing activity in the region to evolve.

It is of great importance to pay attention to these threats as, according to Vianna (2009), with the reduction in the environmental quality of the coastal region and the consequent drop in production, the drive to ensure financial returns has led to small vessels, which generally worked near the coast, having to move out to more distant areas, i.e., those not authorized by the port authorities, thus creating an increased risk for fishermen.

Despite the technologies currently available, most small boats do not have the essential equipment to ensure work and worker safety. In the case of artisanal fishing, work accidents occur because the vessels do not have safety and rescue equipment (VHF radio, life jackets, 
DOI: 10.14807/ijmp.v12i2.1326

buoys, and flags), and also because fishermen are not able to use them and/or repair them (SEAP, 2007).

The analysis herein is important in enabling other studies in this area to be performed. In this study, it was possible to explore the potentialities and vulnerabilities in fishing so that these can adequately be addressed. Thus, relevant changes in the fishing sector can occur, analyzing the factors necessary to attain enhanced activity, and perhaps an optimal IPSP along the coast of the State of Rio de Janeiro.

In spite of its fishing vocation, in the State of Rio de Janeiro fishing activity, and perhaps more importantly the workers in the sector, lack public policies that contribute to the development of fishing. For example, Vianna (2009) reports that if the development of fishing activity is desired, it is necessary to invest in measures that allow the improvement of fisheries management. It is not possible to define and invest in public policies consistent with the current status of fishing in Rio de Janeiro in the face of the existing information gap. Thus, it is imperative to collect data, and systematize and disseminate existing data, especially with regard to information concerning fishermen and fleets, production statistics, accidents, and workrelated diseases.

Several difficulties were encountered in the preparation of this study as it was necessary to undertake continuous updates of the data for the indicators, and these indicators in turn comprised several subdivisions, which had a direct influence on obtaining the indices. Moreover, there was difficulty in finding detailed information and bibliographic materials on fishing activity. Thus, it is critical that developmental research be undertaken to improve techniques and methods in studies such as this. For example, if there were more studies in the area of fishing activities, and techniques and tools, it would increase competitiveness in the national and world scene, in particular because, according to Moura (2008), one of the decisive determinants of competitiveness is the development of technology; in this regard, the research and development undertaken by an organization can lead to competitive advantage.

\section{FINAL CONSIDERATIONS}

As fishing is an activity with historical characteristics, there are many solutions consolidated based on the practice of centuries of accumulated experience and considered to be successful. It is possible to envision a slow process in which both vessels and tools might not evolve particularly rapidly, but without breaking with the basic concepts of fishing activity. This process has taken place in Brazil, but for real development stimuli and specific public 
DOI: 10.14807/ijmp.v12i2.1326

policies for the sector are necessary. Certainly, these need to be suited to the needs and challenges of fishing in Brazil and Rio de Janeiro in particular.

However, despite the difficulties faced, it has been possible to calculate the socioeconomic and productivity indices of the marine and estuarine fishing activity of Rio de Janeiro, concluding that the municipality of Angra dos Reis is the highest ranking in general, and that the economic sub-index has the greatest relevance among the sub-indices for fishing.

It should also be noted that there is no current public policy for the development of the fishing industry as an activity of relevance in Rio de Janeiro. The existing infrastructure supporting fishing is the result of private initiatives on the part of entrepreneurs and professionals who see promise in business in the sector. This study aims to contribute to the development of marine and estuarine fisheries, perhaps as a transforming agent of the local reality, through academic research, thus assisting municipalities in the development of their activities (supporting the elaboration of public policies).

Finally, this study highlights the importance of improvements in this sector due to the great importance of fishing globally as a source of food, and income and employment, as well as the fact that all the municipalities studied have points that need adjustment to enhance development in fisheries.

\section{ACKNOWLEDGMENT}

This study was financed in part by the Coordenação de Aperfeiçoamento de Pessoal de Nível Superior - Brasil (CAPES) - Finance Code 001 and Fundação de Amparo à Pesquisa e Inovação do Espírito Santo (FAPES).

\section{REFERENCES}

Abdallah, P. R. (1998). Atividade pesqueira no Brasil: política e evolução. Tese (Doutorado em Ciências).. Escola Superior de Agricultura Luiz de Queiroz - ESALQ. Universidade de São Paulo. Available: http://bdpi.usp.br/item/001012525. Access: 15/02/2019.

Allison, E. H., Barange, M., \& Dulvy, N. K. (2009). Sustaining fish supplies for food security in a changing climate. In: World Climate Conference-3 (WCC-3)., Geneva. Anais... Leicester: World Meteorological Organization and Tudor Rose Ltd., 59-62.

Andrade, J. C. P., \& Schiavetti A. (2015). Artisanal fishing and local conflicts: the case of the "Pedras de Una" fishing community, Bahia, Brazil. Revista de Gestão Costeira Integrada/Journal of Integrated Coastal Zone Management, 15(3), 425-438.

Assis, M. C., Gomes, V. A. P., Balista, W. C., \& Freitas, R. R. (2017). Use of performance indicators to assess the solid waste management of health services. Anais da Academia Brasileira de Ciências, 89(3Suppl.), 2445-2460. DOI: 10.1590/0001-3765201720170178 
Baker, R., Brick, J. M., Bates, N. A., Battaglia, M., Couper, M. P., Dever, J. A., Gile, K. J., \& Tourangeau, R. (2013). Summary Report of the AAPOR Task Force on Non-probability Sampling. Journal of Survey Statistics and Methodology, 1(2), 90-143. DOI: 10.1093/jssam/smt008

Bornia, A. C., \& Wernke, R. A. (2001). Contabilidade gerencial e os métodos multicriteriais. Revista Contabilidade \& Finanças, FIPECAPI - FEA - USP, 14(25), 60-71. DOI: 10.1590/S1519-70772001000100004

Brasil. (1990). Lei $\mathbf{n}^{\circ} \mathbf{8 . 0 8 0}$, de 19 de setembro de 1990. Dispõem sobre as condições para a promoção, proteção e recuperação da saúde, a organização e o funcionamento dos serviços correspondentes e dá outras providências. Diário Oficial da União, Brasília, DF), 18055. Unpublished. Available: http://www.planalto.gov.br/ccivil_03/leis/l8080.htm. Access: 10/01/2019.

Campos, J. B. (1999). Parque Nacional de Ilha Grande: reconquista e desafios. 2.ed. Maringá: IAP-Coripa, 5000:118. Unpublished.

Carnevalli, J. A., Miguel, P. A. C., \& Salerno, M. S. (2013). Aplicação da modularidade na indústria automobilística: análise a partir de um levantamento tipo survey. Production, 23(2), 329-344. DOI: 10.1590/S0103-65132012005000040

Carvalho, F. E. A., \& Callou, A. B. F. (2008). Extensão pesqueira e desenvolvimento local: a experiência da Secretaria Especial de Aquicultura e Pesca no Estado de Pernambuco, 20032006. Interações, 9(1), 65-76. DOI: 10.1590/S1518-70122008000100007

Cay, T., \& Uyan, M. (2013). Evaluation of reallocation criteria in land consolidation studies using the Analytic Hierarchy Process (AHP).. Land Use Policy, 30(1), 541-548. DOI: 10.1016/j.landusepol.2012.04.023

Corsi, A., Barbosa, D. H., \& Moro, A. M. K. (2020). Alicação da metodologia analytic heirarchy process para a seleção de fornecedores em uma indústria de confecção. Navus, 10, 01-20.

Coutinho, L. (2016). A terceira revolução industrial e tecnológica. As grandes tendências das mudanças. Economia e Sociedade, [s.l.] v. 1(1), 69-87. Available:

https://periodicos.sbu.unicamp.br/ojs/index.php/ecos/article/view/8643306/10830. Access: 08/01/2019.

Dias, T. L. P., Rosa, R. S., \& Damasceno, L. C. P. (2007). Aspectos socioeconômicos, percepção ambiental e perspectivas das mulheres marisqueiras da Reserva de Desenvolvimento Sustentável Ponta do Tubarão (Rio Grande do Norte, Brasil).. Gaia Scientia, 1(1), 25-35. Available:

http://www.periodicos.ufpb.br/index.php/gaia/article/view/2225/1953. Access: 10/01/2019.

Domanski, J. C. (2014). Indicadores de desempenho e sua importância para a gestão. Comunidade ADM. 2014. Available:

http://www.administradores.com.br/artigos/negocios/indicadores-de-desempenho-e-suaimportancia-para-a-gestao/81210. Access: 10/01/2019.

Dresch, A., \& Miguel, P. A. C. (2015). Análise dos principais métodos de pesquisa empregados para a condução de estudos que abordam a inovação no Brasil. GEINTEC Gestão, Inovação e Tecnologias, 5(4), 2480-2494. DOI: 10.7198/geintec.v5i4.522

Dupont, W. D., \& Plummer, W. D. (1990). Power and sample size calculations: a review and computer program. Controlled Clinical Trials, 11(2), 116-128. DOI: 10.1016/01972456(90).90005-M 
Evangelista-Barreto, N. S., Daltro, A. C. S., Silva, I. P., \& Bernardes, F. S. (2014). Indicadores socioeconômicos e percepção ambiental de pescadores em São Francisco do Conde, Bahia. Boletim do Instituto de Pesca, 40(3), 459-470. Available: https://www.pesca.sp.gov.br/40_3-459-470.pdf. Access: 18/12/2018.

Faraco, L. F. D. (2012). Vulnerabilidade de Pescadores Paranaenses às Mudanças Climáticas e os Fatores que Influenciam suas Estratégias de Adaptação. Tese (Doutorado em Meio Ambiente e Desenvolvimento). - Programa de Pós-Graduação em Meio Ambiente e Desenvolvimento, Universidade Federal do Paraná, Curitiba, 261f. Available: https://acervodigital.ufpr.br/bitstream/handle/1884/27744/R\%20-\%20T\%20\%20FARACO\%2c\%20LUIZ\%20FRANCISCO\%20DITZEL.pdf?sequence=1\&isAllowed=y. Access: 10/01/2019.

Faveret, F., Siqueira, P. S. C., \& Gomes, S. H. (1997). Panorama da pesca marítima no mundo e no Brasil. BNDES Setorial, Rio de Janeiro, 5, 185-198. Available: http://web.bndes.gov.br/bib/jspui/handle/1408/3365. Access: 20/01/2019.

FIPERJ (2017). A pesca no Estado do Rio de Janeiro. Rio de Janeiro, Brazil. In: http://www.fiperj.rj.gov.br/index.php/main/pesca

FUNDAÇÃO PROMAR. (2005). Macrodiagnóstico da Pesca Marítima do Estado do Espírito Santo SIG- Pesca ES. 68p. SEAG - Secretaria de Agricultura, Abastecimento e Pesca. Vitória, ES, Brasil. Available: http://docplayer.com.br/10632860-Macrodiagnosticoda-pesca-maritima-do-estado-do-espirito-santo-sig-pesca-es-2005-fpm-rt-005-05-julho05.html. Access: 10/01/2019.

FAO. Fisheries and Aquaculture Department, Food and Agriculture Organization of the United Nations, FAO. (2016). The state of world fisheries and aquaculture. Rome: FAO. Available: http://www.fao.org/3/a-i5555e.pdf, Access: 25/11/2018.

Goode, W. J., \& Hatt, P. K. (2017). Métodos em Pesquisa Social. 424p., 4a ed. São Paulo: Nacional. ISBN: 9788597013832.

Gomes, V. A. P., \& Freitas, R. R. (2018). Índice de potencialidade socioeconômica e produtiva da pesca marinha e estuarina na região norte do espírito santo (IPSP-norte).. Revista Produção Online, 18(1), 36-62. DOI: 10.14488/1676-1901.v18i1.2568

Gomes, V. A. P., Julio, T. S., \& Freitas, R. R. (2016). Ipspa: Construção De Um Índice De Potencialidade Socioeconômico, Produtivo E Ambiental Pesqueiro Utilizando O Método Ahp Ipspa: Construction of an Index of Potential Socioeconomic, Productive and Environmental Fisheries Using Ahp Method. Brazilian Journal of Production Engineering, 2(1), 72-83.

Isaac-Nahum, V. J. (2006). Explotação e manejo dos recursos pesqueiros do litoral amazônico: um desafio para o futuro. Revista Ciência e Cultura, 58(3), 33-36. Available: http://cienciaecultura.bvs.br/pdf/cic/v58n3/a15v58n3.pdf. Access: 05/01/2019.

Kirchner, R. M., Chaves, M. A., Silinske, J., Essi, L., Scherer, M. E., \& Durigon, E. G. (2016). Análise da produção e comercialização do pescado no Brasil. Revista Agroambiente, 10(2), 168-177. DOI: 10.18227/1982-8470ragro.v10i2.2783

Leite, A. M. (1991). Manual de Tecnologia da Pesca. Escola Portuguesa de Pesca, Lisboa.

Breves Notas sobre a História da Pesca, 314p. Available:

http://w3.ualg.pt/ madias/docencia/paq/BrevesNotasHistoriaPesca.pdf. Access: 10/01/2019.

Martins, C. S., Souza, D. O., \& Barros, M. S. (2009). O uso do método de Análise

Hierárquica (AHP). na tomada de decisões gerenciais - Um estudo de caso. XLI SBPO - 
Pesquisa Operacional na Gestão do Conhecimento. p.1778-1788. Available: http://www2.ic.uff.br/ emitacc/AMD/Artigo\%204.pdf. Access: 28/01/2019.

Martins, P. G., \& Laugeni, F. P. (2006). Administração da produção. 562p., 2. ed. São Paulo: Saraiva. ISBN: 9788502046160.

Medeiros Junior, H., Grand Junior, J., \& Figueiredo, J. L. (2011). A importância da economia criativa no desenvolvimento econômico da cidade do Rio de Janeiro. Prefeitura da cidade do Rio de Janeiro, Brazil. Available:

http://portalgeo.rio.rj.gov.br/estudoscariocas/download/3067_A_importancia_da_economia_c criativ_no_Rio_de_Janeiro.pdf. Access: 11/11/2018.

Miguel, P. A. C., Fleury, A., Mello, C. H. P., Nakano, D. N., Lima, E. P., Turrioni, J. B., Ho, L. L., Morabito Neto, R., Martins, R. A., Sousa, R., Costa, S. E. G., \& Pureza, V. M. M. (2012). Metodologia de pesquisa em engenharia de produção e gestão de operações. 280p., 2ªed. Rio de Janeiro: Elsevier. ISBN: 9788535248913.

Moraes, A. O. (2012). Peixes, redes e cidades: aspectos socioambientais da pesca comercial de bagres no médio e Alto Solimões, Amazonas, Brasil. 140p., Dissertação (Mestrado em Ciências do Ambiente e Sustentabilidade)., Programa de Pós-Graduação em Ciências do Ambiente e Sustentabilidade na Amazônia, Universidade Federal do Amazonas, AM, Brasil. Available: https://tede.ufam.edu.br/bitstream/tede/2533/1/andre.pdf. Access: 02/02/2019.

Moura, G. L. (2008). Integração entre P\&D e Planejamento Estratégico. Tese de Doutorado - Universidade de São Paulo, São Paulo. Brasil. DOI: 10.11606/T.12.2008.tde19012009-114758

Nomura, I. O. (2010). O futuro da pesca e da aquicultura marinha no mundo. Ciência e cultura, 62(3), 32-35. Available:

http://cienciaecultura.bvs.br/scielo.php?script=sci_arttext\&pid=S0009-

67252010000300013\&lng=en. Access: 10/01/2019. Access: 10/01/2019.

Oliveira M. A. N., Coelho, R. B. D., \& Amorim, F. A. S. (2009). Análise da Frota Pesqueira do Estado do Rio de Janeiro. In: Vianna, M. (Ed.). Diagnóstico da cadeia produtiva da pesca marítima no Estado do Rio de Janeiro. FAERJ: SEBRAE-RJ, p.91-122.

Oliveira, R. C. O. (2015). Panorama da aquicultura no Brasil: a prática com foco na sustentabilidade. Revista Intertox de toxicologia, risco ambiental e sociedade, REVINTER, 2(1), 71-89. DOI: 10.22280/revintervol2ed1.18

Pizetta, G. T. (2004). Avaliação multidimensional dos sistemas pesqueiros da região sul do Espírito Santo, Brasil, e seus indicadores de sustentabilidade. 72p., Dissertação (Graduação em Oceanografia)., Universidade Federal do Espírito Santo. Vitória, Brasil. Available:

http://www.oceanografia.ufes.br/sites/oceanografia.ufes.br/files/field/anexo/avaliacao_multid imultidime_dos_sistemas_pesqueiros_da_regiao_sul.pdf. Access: 15/12/2018.

Prozee. (2005). Relatório técnico sobre o censo estrutural da pesca artesanal marítima e estuarina nos Estados do Espírito Santo, Rio de Janeiro, Paraná, Santa Catarina e Rio Grande do Sul. Itajaí, Fundação PROZEE (executora)., Convênio SEAP/IBAMA/PROZEE, 151p. Available:

http://www.icmbio.gov.br/cepsul/images/stories/biblioteca/download/estatistica/est_2005_ce nce.pdf. Access: 10/01/2019. 
Rocha, K. S., Silva, R. V., \& Freitas, R. R. (2012). Uma análise da percepção ambiental e transformação socioeconômica de uma comunidade de pescadores artesanais em região estuarina no sudeste do Brasil. Revista da Gestão Costeira Integrada, 12(4), 535-543. DOI: $10.5894 /$ rgci388

Roche, H., \& Vejo, C. (2004). Analisis multicriterio em la toma de deciosiones. Métodos Cuantitativos aplicados a la administración. Analisis multicritério - AHP. Material apoyo AHP, 11p.

Rodrigues, J. A., \& Giudice, D. S. (2011). A pesca marítima artesanal como principal atividade socioeconômica: o caso da localidade de Conceição de Vera Cruz - BA. Revista Cadernos do Logepa, João Pessoa, 6(2), 101-114. Available: http://www.periodicos.ufpb.br/ojs/index.php/logepa/article/view/11738/6954. Access: 19/01/2019.

Saaty T. L. (1990). How to make a decision: The Analytic Hierarchy Process. European Journal of Operational Research, 48, 9-26.

Saaty T. L. (2000). Decision making for leaders. Pittsburg, USA: WS Publications.

SEAP. (2007). Relatório da $5^{\text {a }}$ Seção Ordinária do Subcomitê Científico do Comitê Consultivo Permanente de Gestão dos Recursos Demersais de Profundidade. Secretaria Especial de Aquicultura e Pesca da Presidência da República - SEAP/PR. Itajaí, SC, Brasil. 77p.

Sacco Dos Anjos, F., Niederle, P. A., Schubert, M. N., Schineider, E. P., Grisa, C., \& Caldas, N. V. (2004). Pesca artesanal e pluriatividade: o caso da colônia Z3 em Pelotas, RS. In: II Seminário internacional sobre desenvolvimento local, 2004, Santa Cruz do Sul, RS. Anais... Santa Cruz do Sul. Available: https://www.unisc.br/site/sidr/2004/urbano/08.pdf. Access: 01/12/2018.

Silva, V. L., \& Leitão, M. R. F. A. (2012). A regulação jurídica da pesca artesanal no Brasil e o problema do reconhecimento do trabalho profissional das pescadoras. São Paulo, Brasil. Available:

http://www.ufpb.br/evento/lti/ocs/index.php/17redor/17redor/paper/viewFile/230/103. Access: 17/01/2019.

Soares, A. L. S. (2009). O mercado e a cadeira produtiva do pescado fluminense. In: Vianna M (Ed.).. Diagnóstico da cadeia produtiva da pesca marítima no Estado do Rio de Janeiro. FAERJ: SEBRAE-RJ), 61-90. Available:

https://www.researchgate.net/profile/Marcelo_Vianna2/publication/268208564_A_PRODUC PR_PESQUEIRA_DO_ESTADO_DO_RIO_DE_JANEIRO/links/5463d44e0cf2cb7e9da99a a7/A-PRODUCAO-PESQUEIRA-DO-ESTADO-DO-RIO-DE-JANEIRO.pdf. Access: 10/01/2019.

Steyvers, M. (2002). Multidimensional scaling. In: Encyclopedia of Cognitive Science. Stanford, CA: Stanford University, p.1-5. DOI: 10.1002/0470018860.s00585

Teixeira, J. B., Lima, A. C., Boechat, F. P., Rodrigues, R. L., \& Freitas, R. R. (2012).

Potencialidade social e econômica da pesca e maricultura no Estado do Espírito Santo. Brasil. Revista da Gestão Costeira Integrada, 12(4), 569-575. DOI: 10.5894/rgci372

Tremel, E. (1993). Pesca, novos rumos. Ciclo de palestras sobre temas relacionados ao poder marítimo. Ministério da Marinha, Comando do Quinto Distrito Naval. Florianópolis. Brasil. Available: 
DOI: $10.14807 /$ ijmp.v12i2.1326

http://www.icmbio.gov.br/cepsul/images/stories/biblioteca/download/eventos_cientificos/pal epale_1993_podermaritimo_1.pdf. Access: 10/01/2019.

Vasconcelos, M., Diegues, A. C. S. A., \& Sales, R. R. (2007). Limites e possibilidades na gestão da pesca artesanal costeira. In: Costa Al (Ed.). Nas Redes da Pesca Artesanal. Brasília: IBAMA - MMA), 15-83. Available:

http://www.bdpa.cnptia.embrapa.br/consulta/marc?id=253995. Access: 10/01/2019.

Vianna, M. (2009). Diagnóstico da cadeia produtiva da pesca marítima no Estado do Rio de Janeiro. FAERJ: SEBRAE-RJ: p. 61-90. Available:

https://www.researchgate.net/profile/Marcelo_Vianna2/publication/268208564_A_PRODUC PR_PESQUEIRA_DO_ESTADO_DO_RIO_DE_JANEIRO/links/5463d44e0cf2cb7e9da99a a7/A-PRODUCAO-PESQUEIRA-DO-ESTADO-DO-RIO-DE-JANEIRO.pdf. Access: 10/01/2019.

Viegas, M. C., Moniz, A. B., \& Santos, P. T. (2014). Artisanal fishermen contribution for the integrated and sustainable coastal management - application of strategic SWOT analysis.

Procedia - Social and Behavioral Sciences, 120, 257-267. DOI:

10.1016/j.sbspro.2014.02.103. 